\title{
山梨リニア実験線における速度起電力位相同期方式を用いた 自制制御走行試験結果
}

\author{
正 員 古 賀 俊 作 (東海旅客鉄道株式会社) \\ 正員 北野 淳 一 (東海旅客鉄道株式会社) \\ 正員中島強 (鉄道総合技術研究所)
}

Experimental Results of Self Control System synchronized with Phase of Electromotive Force at the Yamanashi Maglev Test Line

Shunsaku Koga, Member, Jun-ichi Kitano, Member (Central Japan Railway Company)

Tsuyoshi Nakashima, Member (Railway Technical Research Institute)

\begin{abstract}
In the Yamanashi Maglev Test Line, the location of the train is detected with the inductive radio system. The inductive radio system is very reliable and accurate. However using the inductive radio system, we have to lay the cross inductive cable along the guideway accurately and set up the detecting system of train's location in each power conversion station. Therefore the cost of construction and maintenance is very expensive. Moreover, from the redundancy point of view, it is necessary to examine the other method of detecting train's location, in case of inductive radio system down.

We have already proposed a new train's location detecting system using the phase of Electromotive Force (EMF). In this system, the reduced-order state observer estimates the phase of EMF. Therefore the inductive radio system is not required. We have reported the configuration and the basic characteristics of the EMF observer. In this paper, we report the experimental results of running test at the speed of $300 \mathrm{~km} / \mathrm{h} \sim 0 \mathrm{~km} / \mathrm{h}$ in the Yamanashi Maglev Test Line. We confirm the performance of velocity and current control with EMF.
\end{abstract}

キ一ワード : 磁気浮上式鉄道, 位置検知位相, 速度起電力位相, 位相同期制御, 自制制御, 最小次元オブザーバ

\section{1. はじめに}

山梨りニア実験線では，車雨位置に同期した位相を交差 誘導線により検出し，LSMの位相同期制御を行っている(1)。 現在，この位相同期方式では，全線区・全速度域に亘って 安定した特性が得られている。しかしながら,この方式では， 交差誘導線を全線に亘り高精度に教設し，維持管理する必 要があり，設備の施工及び保守に多大な労力が必要となる。 先に，著者らは，交差誘導線方式以外の位置検知方式と して速度起電力位相同期方式を提案し, その理論, シミュレ ーションを示すと共に,インバータ・き電系のミニモデルを使 用して速度起電力位相同期制御系の安定性を実証した (2)。 この方式は, 速度起電力位相を推定し, その推定位相値を 基に，位相同期制御を行う方式であり，設備・保守が軽減さ れるばかりでなく, 制御システム全体の几長性が上がり，信 頼性も向上する。

本論文では，山梨リニア実験線において，速度起電力位 相同期方式を用いた実走行試験を行い，その制御方式の有
効性を確認したので，その試験結果について述へる。速度 起電力推定に基つく実機における位置・速度のセンサレス 制御は，研究室レベルでの比較的規模の小さい回転機制御 で例は見られるが(3)，大規模な鉄道制御システムにおいて 適用された例はこれまで見当たらない。また，本論文で検証 する制御方式は，ロバスト性を有するオブザーバで推定した $\mathrm{d}, \mathrm{q}$ 軸の速度起電力の比から位相偏差を求め, その位相偏 差により入力位相を補正し,さらにPLLにより出力位相として 安定した位相基準を得ることで，低速度域でも速度起電力 位相による安定した走行制御が可能である特徽を有する。 本論文における速度起電力位相による走行試験結果では, 約 $300 \mathrm{~km} / \mathrm{h}$ の高速域から $0 \mathrm{~km} / \mathrm{h}$ の停止までにおける定常特 性，過渡特性及び停止制御特性を示し，提案した制御方式 の有効性を検証する。

\section{2. 速度起電力位相同期制御系硬要}

く2・1> 連転制御システムの概要 図1に山梨リニア実 験線列車運転制御システムの概要を示す。運行管理システ 
ムからは, 列車の走り方を定めたランカーブが駆動制御シス テム人送出される。位置检知装置からは列車位置に対応す る位置検知位相が駆動制御システム人送出される。駆動制 御システムは、これらの情報を基に，電流指令值及び車両と 同期をとるための位相基準を電力変換器へ出力する。電力 変換器から出力される電力は, き電区分制御部により制御さ れるき電区分開閉装置が投入されることにより，列車の在線 する近傍の3系分のセクションのみに供給される。例えば， 図1ではC1，A2，B2セクションのみに供給される。

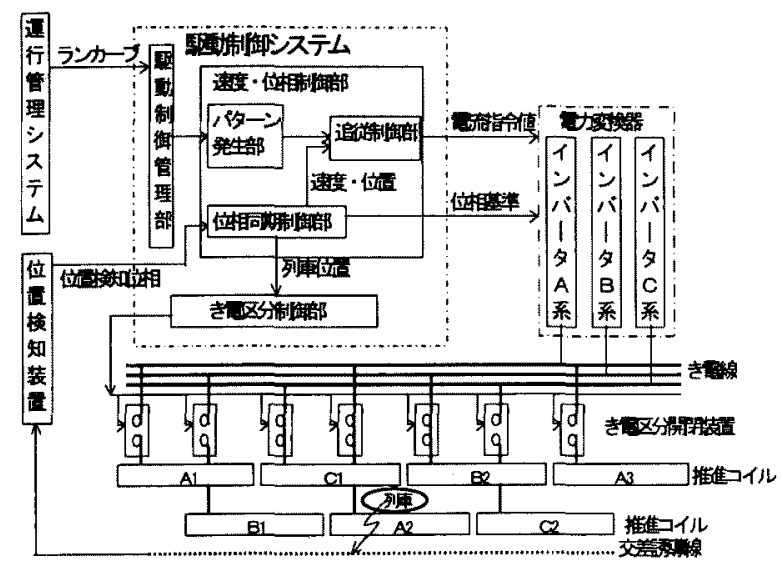

図 1 列車運転制御システムの概要

Fig.1. Overview of train control system

<2-2>EMF方式制御系の硬要 図 2 にEMF方式制御 䒺のブロック線図を示す。

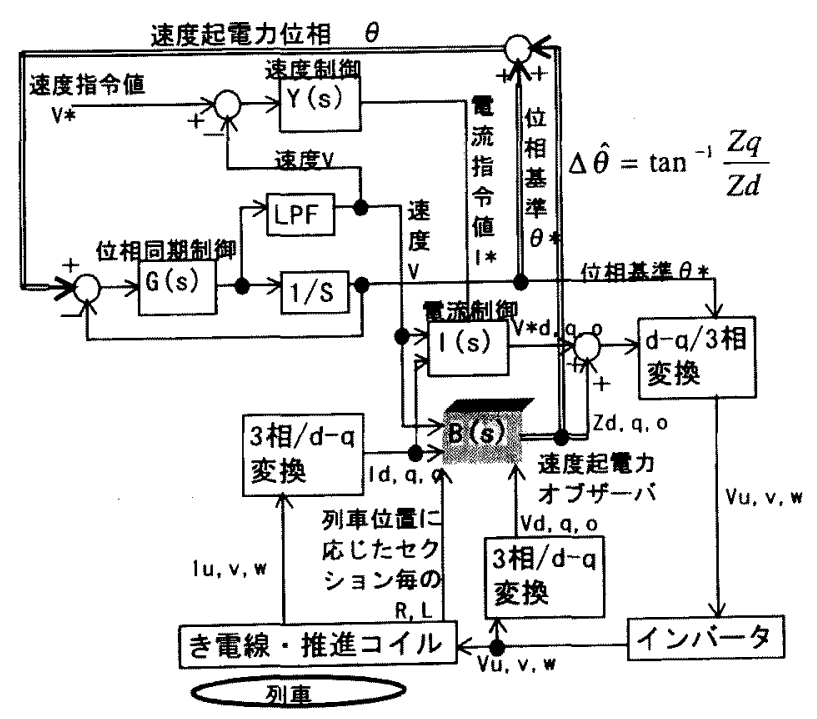

図2 EMF方式制御系ブロック線図

Fig.2. Block diagram of EMF method
速度制御部Y(s)では，位相同期制御部で演算され2次の LPFを通った速度Vと速度指令值 $\mathrm{V}^{*}$ の速度偏差に対し，1 次のPI制御により電流指令值I*を出力する。速度制御部フ ロック線図を図3に示す。

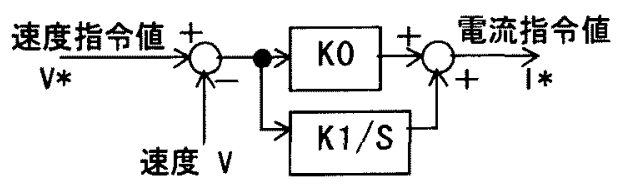

図3 速度制御部Y(s)ブロック楾図

Fig.3. Block Diagram of Velocity control $\mathrm{Y}(\mathrm{s})$

位相同期制御部G(s)では, $5 \mathrm{~ms}$ 周期で速度起電力オブザ 一バにより推定された速度起電力位相 $\theta$ を入力位相として 取り込み，PLLを介して出力位相である位相基準 $\theta$ *を出力 する。位相基準は200 $\mu$ 周期で変換器制御一出力している。 位相同期制御部ブロック線図を図4に示す。

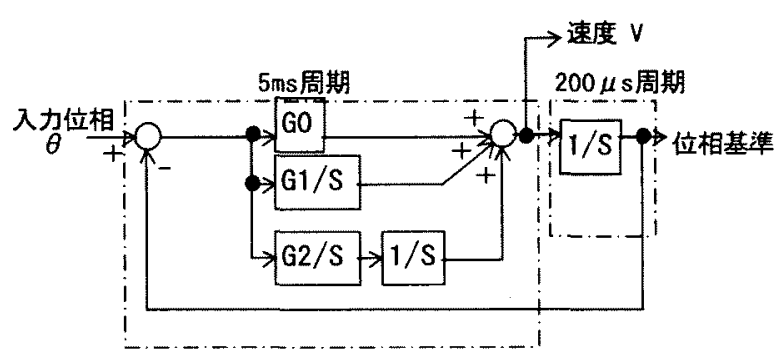

図4 位相同期制御部G(s)ブロック線図

Fig.4. Block diagram of compensating velocity $G(s)$

電流制御部I(s)では，電流指令值 I* と出力電流 I との電 流偏差に对し，1次のPI制御により電圧指令值V*を出力す る。電圧指令值は,オブザーバにより推定された速度起電力 の外乱補償が行われる。電流制御部ブロック線図を図5に示 す。尚，図2～図6におけるR及びLは，車雨位置に応じたセ クション固有の值を切り替えて用いている。

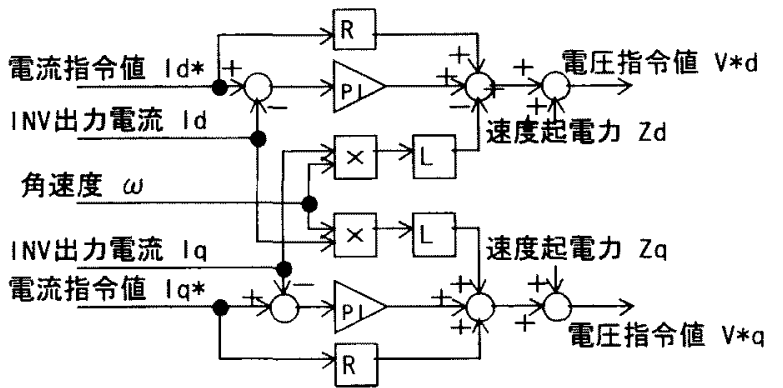

図5 電流制御部I(s)ブロック線図

Fig.5. Block diagram of current control I(s)

速度起電力は, 出力電流I及び出力電圧Vから図6に示す 最小次元オブザーバより推定される。オブザーバダインは， 
オブザーバより上位の制御系である位相同期制御部の応答 時定数より十分高速となり且つ電流検出のフィルタや制御装 置内部の遅れの影響を受けないように,これらの時間よりは 十分達くなるような值を選択している。速度起電力位相は， 速度起電力オブザーバにより推定された速度起電力 $\mathrm{d}, \mathrm{q}$ 成 分 $\mathrm{Zd}, \mathrm{Zq}$ から位相基淮の補正分 $\Delta \hat{\theta}$ を(1)式により求め，位 相同期制御部で演算された位相基準 $\theta$ *に加えることで求 める。その速度起電力位相はPLLを介して変換器電流制御 の位相基準として出力されるため，低速度域でも速度起電 力位相により，安定した速度制御が可能となる。尚，詳細の 理論は文献(2)を参照されたい。

$$
\Delta \hat{\theta}=\tan ^{-1} \frac{Z q}{Z d}
$$

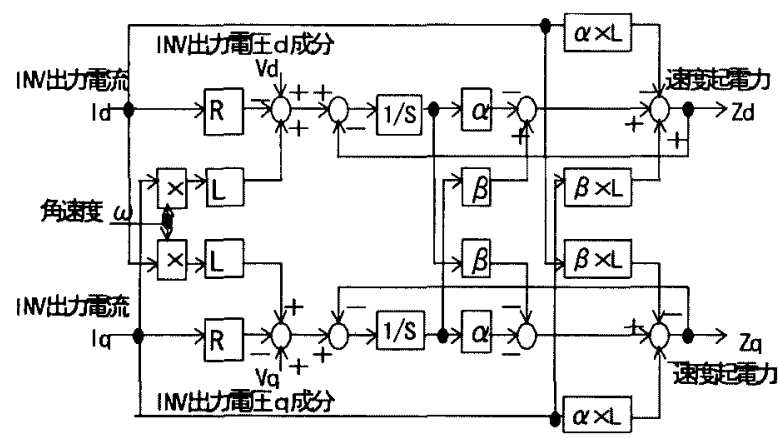

図6 速度起電力オブザーバB(s)ブロック線図

Fig.6. Block diagram of EMF observer $B(s)$

速度起電力位相は, A,B,C 3系分が変換器制御部より送信 されるが，そのうち有効な1系分を位相同期制御部にて図 7 のように選択し，速度起電力入力位相としている。表1に走 行試験に用いた電力変換器及び車両の諸元を示す。

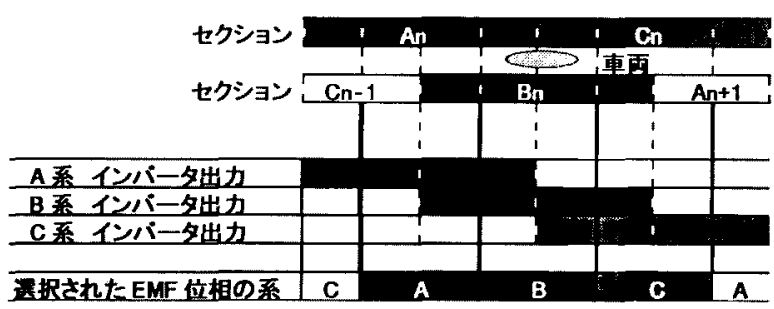

図 7 速度起電力位相選択

Fig.7. Select method of EMF

表 1 電力変換器及び車両の諸元

Table.1. Specifications of power conversion system and vehicle

\begin{tabular}{|c|c|c|c|c|c|c|c|}
\hline & 項目 & 值 & 単位 & & 項目 & 值 & 単位 \\
\hline & 容量 & 20 & MVA & & \begin{tabular}{|l} 
編成長 \\
\end{tabular} & 77.6 (3両) & $\mathrm{m}$ \\
\hline & 入力電圧 & DC 5.25 & $\mathrm{kV}$ & 車 & 車两重量 & 80 (3両) & $t$ \\
\hline バ & 出力電圧 & AC 11 & $\mathrm{kV}$ & 両 & 台車方式 & 連接台車 & \\
\hline 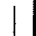 & 出力電流 & 1015 & A & 仕 & 極数 & 4 極2列 & \\
\hline 夕 & 周波数 & $0 \sim 46.3$ & $\mathrm{~Hz}$ & 様 & $\begin{array}{l}\text { 極ピッチ } \\
\text { 起磁力 }\end{array}$ & $\begin{array}{l}1.35 \\
700\end{array}$ & $\underset{\mathrm{kA}}{\mathrm{m}}$ \\
\hline
\end{tabular}

3.速度起電力位相による高速度域走行証㕉结果 <3.1> 走行試験パターン 走行試験時の走行パターンを 図 8 に示す。速度起電力位相による走行区間は, 図 8 中 にEMF適用区間と記した区間で速度は300km/h $215 \mathrm{~km} / \mathrm{h}$, 減速度 $-0.2 \mathrm{~g}$ の区間である。

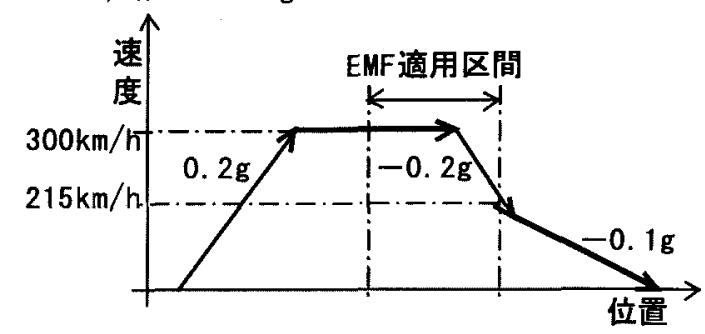

図8 高速度域走行試験パターン

Fig.8. Running test pattern at high speed range

$\langle 3-2\rangle$ 定常特性 図 9 に, 図 8 の走行パターンで走 行試験を行った時の走行全体のチャートを示す。位相, 電流，電圧及び速度は，@で示したEMF適用区間でも安 定した制御特性を示している。特にインバー夕電流では, $\mathrm{d}$ 軸電流は電流指令值通り出力されており，また $\mathrm{q}$ 軸電 流はほとんど0であり，力率 1 の良好な電流制御が行わ れていることが分かる。

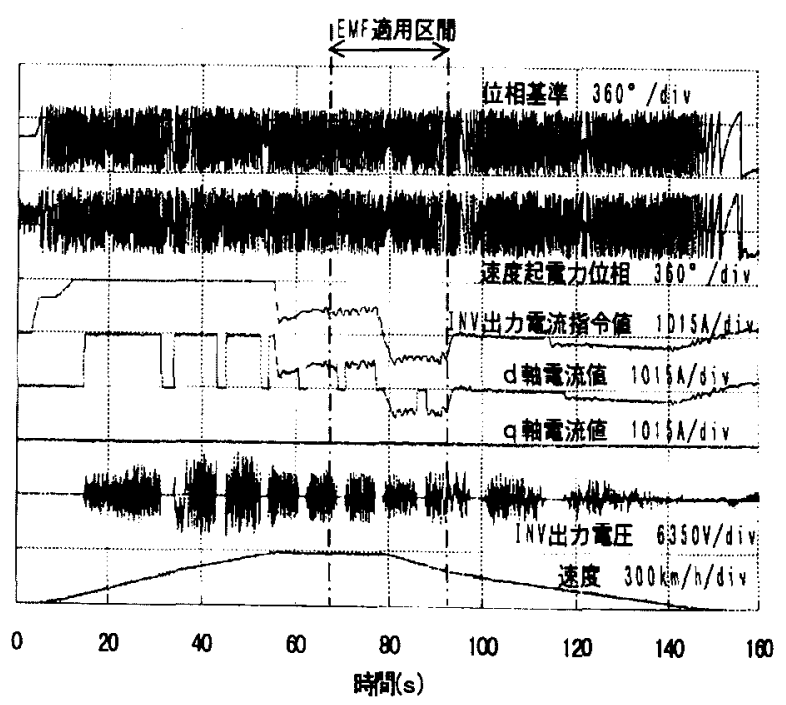

図 9 速度起電力位相走行制御特性

Fig.9. Characteristics of EMF running test

図 10 に $300 \mathrm{~km} / \mathrm{h}$ 一定速度走行時の拡大チャートを示す。 速度起電力位相は, 図4で記した通り $5 \mathrm{~m} \mathrm{~s}$ 周期で入力 されるため階段状の波形となっているが, 特に大きな位 相飛びや歪みも無く安定した速度起電力位相が推定され ている。この速度起電力位相を入力位相として位相同期 制御部で $200 \mu \mathrm{s}$ 毎の補正を行い, 变換器制御の基となる 
位相基進をPLLを介して出力しているため，位相基淮も 同様に安定した波形が得られている。

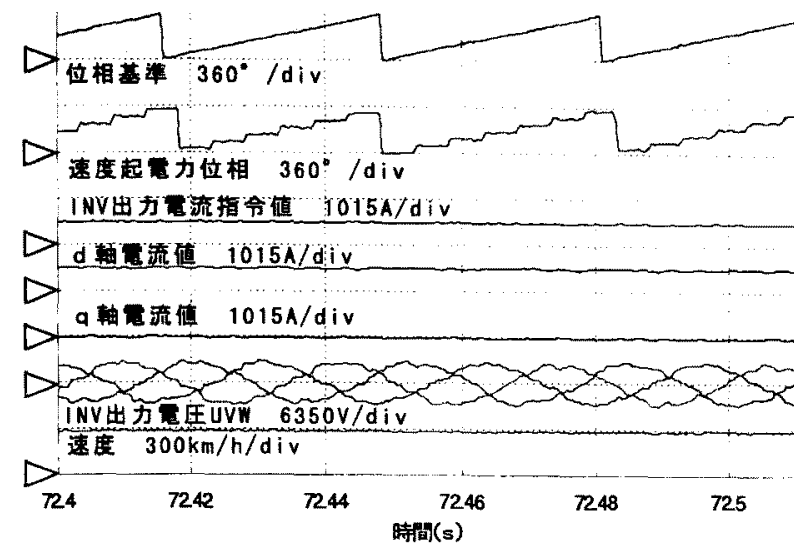

図10 300 km/h 時におけるEMF走行制御特性

Fig.10 Characteristics of EMF running test at $300 \mathrm{~km} / \mathrm{h}$

以上のように, $300 \mathrm{~km} / \mathrm{h}$ 高速走行時の定常特性は，速度起 電力位相及びインバータ出力電流が，位置検知位相使用時 と同等に安定しており,オブザーバーにより推定された速度 起電力位相は走行制御に十分適用可能である。

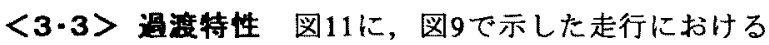
$300 \mathrm{~km} / \mathrm{h}$ 一定速から-0.2 诚速移行時の应大チャートを示 す。過渡時でも，速度起電力位相及び位相基準とも安定 した位相が得られている。また,インバータ出力電流は, $\mathrm{d}$ 軸 $\mathrm{q}$ 軸とも定常状態時と同様に良好に制御されている。 以上より加減速度変化点での過渡特性も安定した制御特 性が得られていることが分かる。

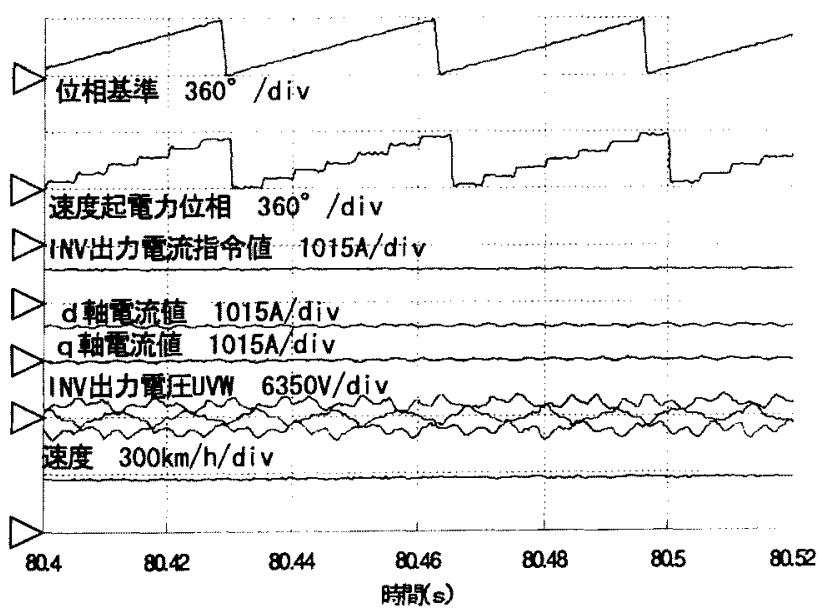

図11速度起電力位相制御時における過渡特性

Fig.11. Transient characteristics if EMF control

<3.4> 入力位相切替時の特性入力位相切替時に おける，位相制御特性について検証する。
$<3-4 \cdot 1>$ 位苜検知位相から速度起電力位相への切替

図 12 に位置検知位相(IR)から速度起電力位相 $(E M F)$ 人 の入力位相切替点におりる位相特性を示す。位相切替点 より前の区間では位相基淮は位固検知位相に同期し，後 の区間では速度起電力位相に同期している。位相切替点 では，位置検知位相と速度起電力位相がほぼ同等の位相 を示しているため，切替時における位相偏差はほとんど 見られず，また速度の変動も無い。 位相切替点 位面模知位相

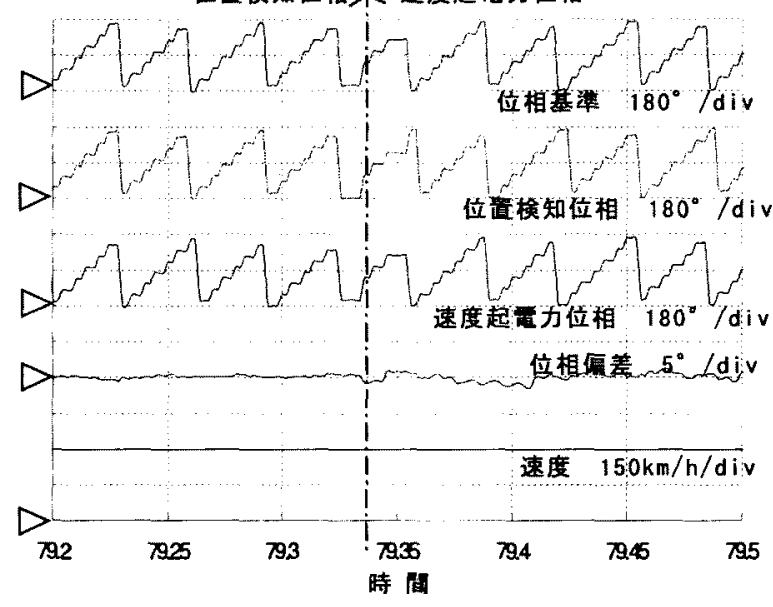

図12 位置検知位相加ら速度起電力位相人の切替

Fig.12 Changing phase from IR to EMF

\section{<3-4-2>速度起電力位相から位置検知位相への切替}

図13に速度起電力位相から位置検知位相への入力位相切 替点における位相特性を示す。この位相切替点では, 約8 度の位相偏差が生じている。主な原因としては, 図12に おける位相切替点は $300 \mathrm{~km} / \mathrm{h}$ 等速時定常状態での切替で あるのに対し，図13の切替は-0.2 g 減速中の過渡状態 位相切替点

\section{速度起電力位相 米位置揄知位相}

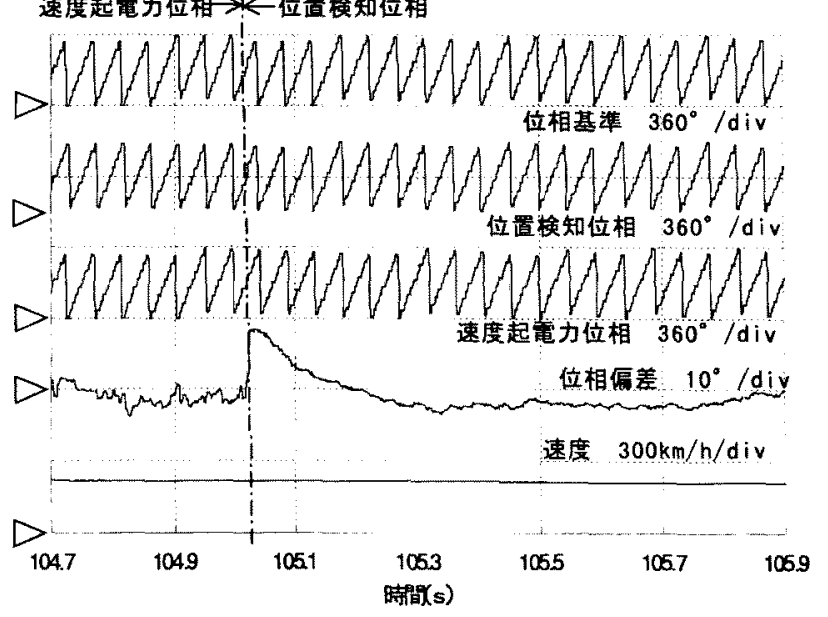

図13速度起電力位相から位圈検知位相への切替

Fig.13 Changing phase from EMF to IR 
における切替であり，また位置榆知位相と速度起電力位 相は非同期であることによる。切替点で 8 度あった位相 偏差は，䄪 1 秒後には 0 度に収束しており，図14のシミ エレーション結果と良く一致している。位相偏差 8 度に おける推力変動は約 $1 \%$ であるが，図13の速度チャート は切替点において変動しておらず，切替時の位相偏差は， 速度制御特性に影響を与えず，問題のないことが分かる。

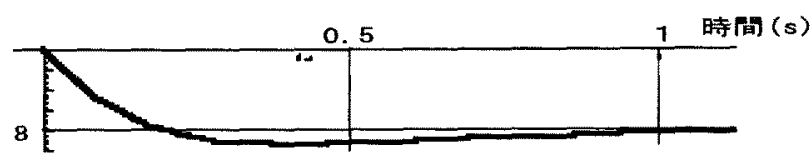

位相偏差 $\left(^{\circ}\right)$

図14 位相同期制御における $8^{\circ}$ ステップ応答

Fig.14 Step response of PLL

\section{<3-4-3> 速度起電力位相の系切替}

図15にA系からC系人の速度起電力位相切替時におけ る位相特性を示す。図 7 でも説明した通り，入力位相と しての速度起電力位相は，3系の内最も安定して速度起 電力位相の出力されているき電セクション中間付近の速 度起電力位相を選択するようにしている。図15の区間で は，A系とC系の間に車兩が存在し，B采のインバー夕は 停止しているためB系の速度起電力位相は出力されてい ない。3系のインバータは，相互干涉無く制御されてい るため, 速度起電力位相は 3 系とも非同期であるが，図 15における位相切替点での位相偏差は，通常時の位相偏 差の傾向と変わりなく，若干発生しているが, 速度特性 に変化は無く, 速度起電力位相の系切替による速度制御 系への影響は無いことが分かる。

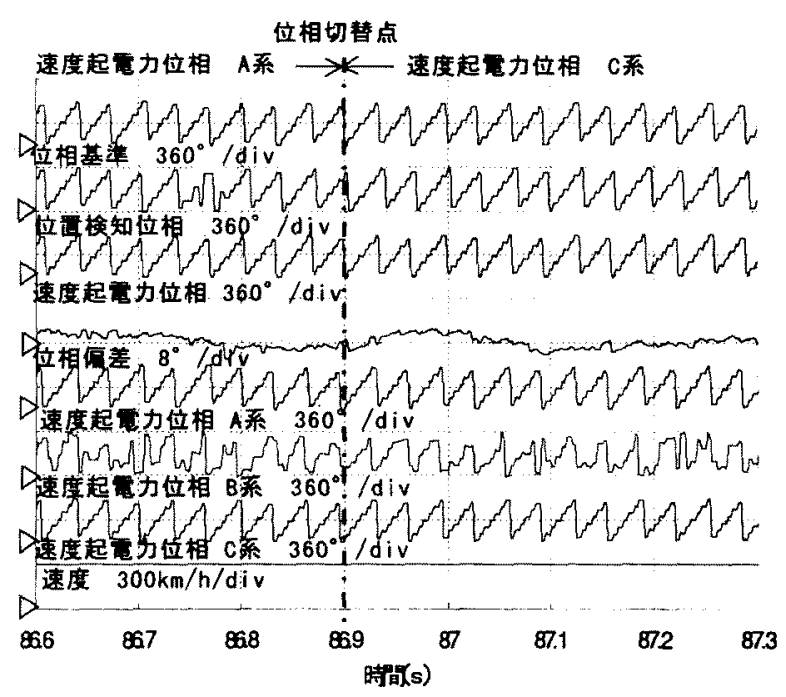

図 15 速度起電力位相の采切替

Fig. 15 Changing phase from A-EMF to C-EMF

\section{4.速度起電力位相による低速度域走行試㰸结果} $\langle 4 \cdot 1>$ 低速度走行時における制胙特性图16に, 速 度起電力の小さい低速域である速度 $67 \mathrm{~km} / \mathrm{h} \sim 0 \mathrm{~km} / \mathrm{h}$ 停止 までの開で速度起電力位相制御を適用した時の走行制御 試験結果を示す。

速度起電力位相は, 低速時でも大きな乱れはなく, 位相 基淮は安定して出力されていることが分かる。また，インバ 一夕電流は, $\mathrm{d}$ 軸電流は電流指令值通り出力され $\mathrm{q}$ 軸電 流はほとんど0であり，良好な電流制御が行われている ことが分かる。

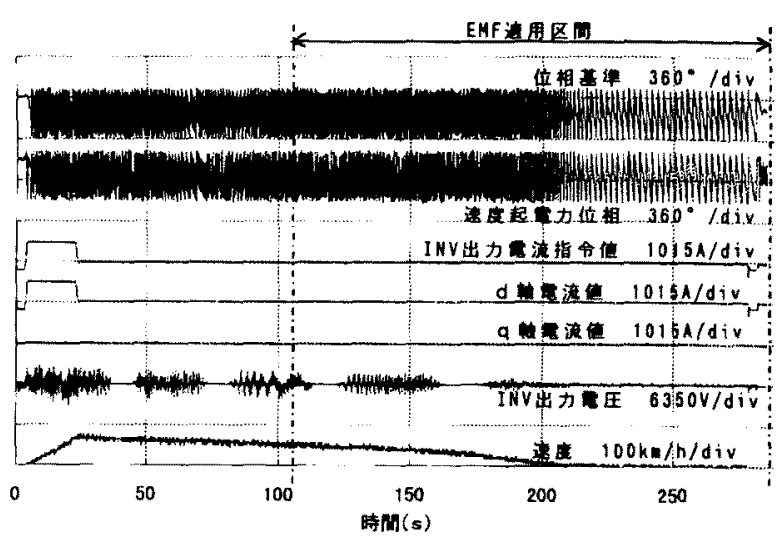

図16 低速時における速度起電力位相走行制御特性

Fig.16 Characteristics of EMF running test at low speed

<4-2〉停止時における制作特性図17に，図16におけ る停止時の走行制御特性拡大図を示す。

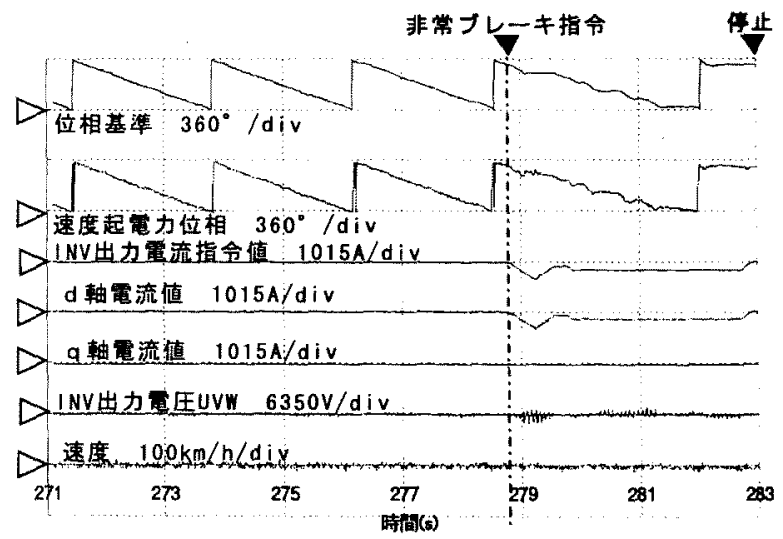

図 17 停止時の速度起電力位相走行制御特性

Fig.17 Characteristics of EMF running test at stopping

停止時の試験では，急激な堿速度でも停止出来ること を確認するため，非常ブレーキを指令し停止させる試験 を行った。国17では約 $4 \mathrm{~km} / \mathrm{h}$ 時，図中齐付した時点で 非常ブレーキが指令され，その直後約 $-400 \mathrm{~A}$ の回生電流 
が流れ，それに伴い速度起電力位相及び位相基準は若干 乱れているが, 電流の収束する停止時は位相も安定して おり, 速度 $0 \mathrm{~km} / \mathrm{h}$ の停止まで, 速度起電力位相による走 行制御が良好に行われていることが分かる。

停止付近でも速度起電力位相により安定した制御が可 能である理由として, 以下の 4 点をあげることが出来る。 (1)出力電流 $\mathrm{I}=0(\mathrm{~A})$ となる停止制御では, 速度起電力Zを

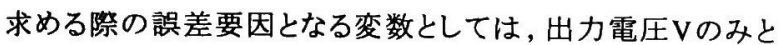
なり, 速度起電力を推定する際の誤差要因が小さい。

(2)速度起電力位相検出限界付近でも, PLLのフィルター機 能により位相を正整可能である。

(3) $\mathrm{d}, \mathrm{q}$ 軸の速度起電力の比より位相基準を補正しているた め,位相基準が安定する。

(4)速度が $0.2 \mathrm{~km} / \mathrm{h}$ 以下となると,ディスクブレーキ動作により

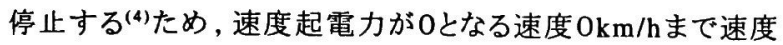
起電力位相により制御する必要はない。

なお，停止時は，以上の理由により，速度起電力位相によ

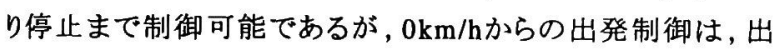
発時に速度起電力が発生しないため, 模擬位相による制御 が必要となる。

\section{5. まとめ}

本論文では，先に発表した論文「磁気浮上式鉄道にお ける速度起電力位相を用いた自制制御」(2)における理論を 检証するための実列車による走行試験結果を示した。その 結果 $300 \mathrm{~km} / \mathrm{h}$ における高速走行, $-0.2 \mathrm{~g}$ における減速走行, 約 $60 \mathrm{~km} / \mathrm{h}$ 以下における低速走行及び非常ブレーキにおけ る停止共に速度起電力位相は安定に推定され変換器制御 の基となる位相基準及びインバータ出ガd軸 $\mathrm{q}$ 軸電流とも良 好に制御され速度起電力位相による走行制御に問題のない ことが検証された。今後は文献(2)で示した模擬位相を利用 した他制制御による出発制御の検討を進め, 出発から停止 まで位置検知位相に㑈らない位㯰・速度センサレス制御の 走行試験を行う予定である。最後に、この試験を進めるにあ たり，山梨実験センター,JR東海リニア開発本部及び三菱電 機(株)の多くの方々に, 御協力頂き感謝致します。また, 本 研究は運輸省国庫補助金を受けて行った。 (平成 11 年08月 30 日受付、平成 12 年01月 06 日再受付)

\section{文献}

(1) 長田豊,他:「山梨りニア実験線の駆動制御システム」, 電学論 D,Vol. 119, No3, P308〜P313，1999年

(2) 古賀俊作, 他:「磁気浮上式鉄道における速度起電力同期方 式を用いた自制制御」, 電学論D,Vol.119, No6, P816〜 P824, 1999年

（3）竹下隆晴, 他: 「速度起電力推定に基つくくンサレス突極形ブラ シレスDCモータ制御」, 電学論D, Vol.117, No1,P98〜P104, 1997年

(4)古賀倰作, 他:「磁気浮上式鉄道における停止制御」, 電学論 $D$, Vol.119,No11, P1301〜P1306, 1999年

古賀拨作 (正員) 平成3年3月早稲田大学理工学研究科

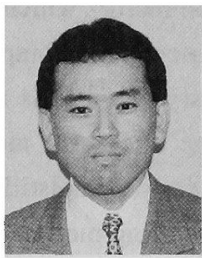
電気工学修士課程修了。同年 4 月東海旅客 鉄道株式会社入社。以来, 主に, 超電導磁気 浮上式鉄道電力設備, 駆動制御の開発に従 事。工学博士

北野 淳一

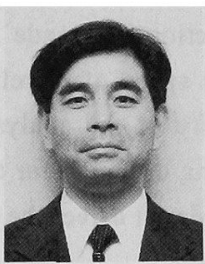

中島強 (正員) 昭和 57 年3月中央鉄道学園大学課程電

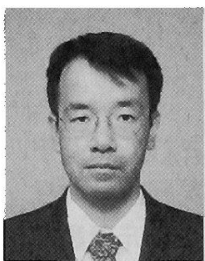

(正員) 昭和 57 年 3 月東京工業大学大学院理 工学研究科電気・電子工学専攻修士課程修 了。昭和 60 年 3 月同博士課程単位修得退学。 同年 4 月同大学工学部助手。平成元年 4 月東 海旅客鉄道株式会社入社。以来, 超電導磁 気浮上式鉄道の開発に従事。

気科卒業。59年3月より宮崎浮上式鉄道実験 センター, 鉄道総合技術研究所にて浮上式 鉄道の研究開発に従事。現在, 鉄道総合研 究所にて浮上式鉄道の電力供給システムに 関する研究開発を担当。 